\title{
PENGARUH MOTIVASI TERHADAP KINERJA KARYAWAN DENGAN KOMITMEN ORGANISASI SEBAGAI VARIABEL INTERVENING PADA UPT SUNGAI DUKU PEKANBARU
}

\author{
Ali Umar \\ STIE Bangkinang \\ Suarni Norawati \\ STIE Bangkinang \\ suarni.norawati@yahooo.co.id
}

\begin{abstract}
Performance appraisal is an important thing for every leader of an organization, both public and private organizations. Many factors affect performance either directly or indirectly. This research was conducted at UPT Sungai Duku Pekanbaru and this study aims to determine the effect of motivation on performance, motivation on organizational commitment and the effect of organizational commitment on performance. This study uses primary data and secondary data, where primary data were obtained from seventy-three employees as samples. Data was collected by means of interviews, questionnaires and documentation. Data analysis was carried out using the SEM (Structural Equition Model) method and assisted by the SmartPLS version 3.00 program. The results of this study conclude that there is a significant influence of the motivational variable on performance, a significant influence of motivation on organizational commitment and there is a significant influence of organizational commitment on performance.
\end{abstract}

Keywords $\quad$ Work Motivation, Organizational Commitment, Performance

\section{PENDAHULUAN}

Pengelolaan SDM adalah suatu kebutuhan vital bagi perusahaan yang memerlukan perhatian serta perlakuan khusus tersendiri. Hal ini dikarenakan sumber daya manusia tidaklah sama seperti sumber daya lainnya dalam perusahaan. Selain itu, pengelolaan SDM juga erat terhadap peningkatan kinerja karyawan di suatu perusahaan dimana pemberian motivasi oleh perusahaan dan komitmen karyawan terhadap organisasi juga memiliki andil dalam peningkatan kinerja karyawan. Paita,dkk. (2015) menjelaskan kinerja sebagai hasil kerja dari setiap individu dari pekerjaan dalam organisasinya dalam kurun waktu tertentu. Kinerja yang tinggi dapat dihasilkan salah satunya dengan adanya motivasi yang diberikan oleh perusahaan. Uno (2014) mendefinisikan motivasi sebagai faktor yang ikut menentukan kinerja karyawan, yang besar kecilnya pengaruh motivasi terhadap kinerja karyawan tergantung daripada intensitas motivasi yang diberikan oleh sebuah perusahaan kepada karyawannya.

Motivasi yang diberikan perusahaan tidak hanya akan mampu mempengaruhi kinerja karyawan. Motivasi tersebut juga dapat mempengaruhi komitmen organisasi dari karyawan. Luthans (2011) mendefinisikan komitmen organisasi sebagai keinginan yang kuat untuk tetap menjadi anggota organisasi, keinginan untuk berusaha sekuat tenaga demi organisasi dan kepercayaan yang pasti dan penerimaan terhadap nilai-nilai dan 
tujuan organisasi. Hunt and Morgan dalam Sopiah (2008), karyawan yang memiliki komitmen organisasi yang tinggi akan memiliki kepercayaan dan menerima tujuan dan nilai organisasi, berkeinginan untuk mencapai tujuan organisasi, dan memiliki keinginan yang kuat untuk bertahan dalam organisasi.

UPT Sungai Duku merupakan satu-satunya pelabuhan yang ada Pekanbaru yang terletak di tepi Sungai Siak dan berjarak 96 mil ke muara sungai, menjadi sarana transportasi untuk komoditi ekspor seperti kelapa sawit. Selain itu, pelabuhan ini juga menghubungkan Pekanbaru dengan kawasan di pesisir Provinsi Riau seperti Selat Panjang, Bengkalis, Siak Sri Indrapura, Sei Pakning dan lain sebagianya serta kota-kota di Kepulauan Riau, seperti Tanjungpinang dan Batam. Selain itu, Pelabuhan Sungai Duku saat ini sudah mempekerjakan sebanyak 73 orang karyawan, dimana sebelum mengawali kegiatannya, setiap hari senin pagi sebelum memulai aktivitas selalu mengajak seluruh karyawannya untuk berkumpul di lantai dasar tepatnya di lobby gedung utama untuk melaksanakan kegiatan. Kegiatan ini bertujuan untuk memotivasi para karyawan sebelum melaksanakan pekerjaannya, dengan berbagi cerita motivasi atau dengan membagikan pengalaman yang menginspirasi selama seminggu sebelumnya dalam pekerjaan. Perusahaan menilai kinerja karyawan pada Pelabuhan Sungai Duku dengan adanya Sistem Manajemen Kinerja Pegawai (SMKP). SMKP tersebut digunakan untuk menilai kinerja para karyawan yang dilakukan setiap tahun yang bertujuan untuk meningkatkan kinerja karyawan. Karena kinerjanya akan dinilai maka karyawan akan terus bersemangat untuk meningkatkan kinerjanya. Kinerja karyawan yang semakin tinggi dinilai bahwa karyawan tersebut memiliki komitmen organisasi yang tinggi.

Fenomena yang terjadi dalam perusahaan saat ini adalah adanya laporan dari para atasan terkait adanya permasalahan kinerja karyawan bahwa kinerja karyawan masih dirasa kurang baik. Hal tersebut antara lain adalah kedisiplinan karyawan, dibuktikan dari hasil wawancara dengan bagian kepegawaian terkait dengan masih adanya beberapa karyawan yang datang terlambat masuk kerja. Masih ada permasalahan yang terkait dengan perilaku karyawan yang dirasa tidak sesuai dengan nilai-nilai instansi serta masih adanya pegawai yang belum mampu melakukan pengembangan tugas yang telah dibebankan kepadanya. Dari hasil wawancara dengan 8 karyawan tetap yang mengatakan bahwa nilai-nilai budaya instansi selama ini telah diamalkan, namun tidak menutup kemungkinan jika masih ada pegawai yang melanggar peraturan yang ada. Hal ini mengindikasikan komitmen pegawai terhadap instansi masih rendah.

Dan dari hasil wawancara dengan 8 pegawai tetap UPT Pelabuhan Sungai Duku Pekanbaru mengatakan bahwa mereka mengharapkan perlu adanya penghargaan dari perusahaan atas prestasi mereka dalam melaksanakan tugas yang sudah di berikan oleh pimpinan kepada karyawan. Selama ini di intansi UPT Pelabuhan Sungai Duku Pekanbaru masih belum dapat memberikan apresiasi khusus bagi karyawan yang berpretasi atau karyawan yang memilki kinerja yang berkinerja tinggi. Para karyawan menganggap dengan pemberian penghargaan tersebut, karyawan akan merasa lebih dihargai hasil kerjanya sehingga kinerja mereka pun akan semakin terpacu meningkat. Berdasarkan beberapa uraian diatas, dapat diidentifikasi masalah adalah masih rendahnya komitmen karyawan dalam melaksakan tugas dan menerapkan kedisiplinan dalam bekerja, hal ini terlihat dari tanggapan responden dari hasil wawancara dengan beberapa karyawan pada saat survey. Pada penelitian ini juga terindikasi rendahnya kinerja pegawai, hal ini dikarenakan masih belum adanya penghargaan dari pimpina terhadap capaian pegawai dalam melaksanakan pekerjaannya. Hasil pada saat pra survey juga menemukan masih dendajnya motivasi kerja pegawai. Hal ini terlihat dari masih 
banyak pegawai yang melanggar disiplin seperti keterlambatan masuk kerja. Masih rendahnya perhatian pimpinan instansi yaitu pimpinan UPT Pelabuhan Sungai Duku Pekanbaru terhadap capaian hasil kerja pegawai, sehingga pegawai tidak termotivasi untuk berkerja dengan baik.

Berdasarkan latar belakang diatas, maka permasalahan penelitian ini yaitu bagaimana pengaruh motivasi terhadap komitmen organisasi, bagaimana pengaruh motivasi terhadap kinerja karyawan pada UPT Sungai Duku Pekanbaru. Dan bagaimana pengaruh komitmen organisasi terhadap kinerja. Tujuan penelitian ini adalah untuk menganalisa dan mengetahui pengaruh motivasi terhadap komitmen organisasi, untuk menganalisa dan mengetahui pengaruh motivasi terhadap kinerja karyawan, untuk menganalisa dan mengetahui pengaruh komitmen organisasi terhadap kinerja karyawan pada UPT Sungai Duku Pekanbaru.

\section{LANDASAN TEORI \\ Teori Kinerja}

Kinerja adalah hasil dari suatu proses yang mengacu dan diukur selama periode waktu tertentu berdasarkan ketentuan atau kesepakatan yang telah ditetapkan sebelumnya. Menurut Sutrisno (2012) kinerja adalah hasil kerja karyawan dilihat dari aspek kualitas, kuantitas, waktu kerja, dan kerja sama untuk mencapai tujuan yang telah ditetapkan oleh organisasi. Menurut Mangkunegara (2013) kinerja adalah hasil kerja secara kualitas dan kuantitas yang dicapai oleh seorang pegawai dalam melaksanakan tugasnya sesuai dengan tanggung jawab yang diberikan kepadanya. Menurut Fahmi (2017), kinerja adalah hasil dari suatu proses yang mengacu dan diukur selama periode waktu tertentu berdasarkan ketentuan atau kesepakatan yang telah ditetapkan sebelumnya. Menurut Torang (2013), kinerja adalah kuantitas atau kualitas hasil kerja individu atau sekelompok didalam organisasi dalam melaksanakan tugas pokok dan fungsi yang berpedoman pada norma, standard operasional prosedur, kriteria dan ukuran yang telah ditetapkan atau yang berlaku dalam organisasi.

Dari teori-teori yang diketahui diatas maka peneliti mengambil kesimpulan bahwa kinerja adalah suatu proses atau hasil kerja yang dihasilkan oleh pegawai melalui beberapa aspek yang harus dilalui serta memiliki tahapan-tahapan untuk mencapainya dan bertujuan untuk meningkatkan kinerja pegawai itu sendiri.Maka dari itu kinerja merupakan elemen yang penting dalam maju mundurnya suatu organisasi. Karena kinerja merupakan cerminan bagaimana suatu organisasi itu berjalan ke arah yang benar atauhanya berjalan ditempat saja. Menurut Sutrisno (2012:9), faktor-faktor yang mempengaruhi kinerja adalah sebagai berikut :

1. Efektivitas dan efisiensi. Dalam hubungannya dengan kinerja organisasi, maka ukuran baik buruknya kinerja diukur oleh efektivitas dan efesiensi. Dikatakan efektif bila mencapai tujuan, dikatakan efesien bila hal itu memuaskan sebagai pendorong mencapai tujuan, terlepas dari apakah efektif atau tidak.

2. Otoritas dan Tanggung Jawab. Dalam organisasi yang baik wewenang dan tanggung jawab telah didelegasikan dengan baik, tanpa adanya tumpang-tindih tugas. Masingmasing karyawan yang ada dalam organisasi mengetahui apa yang menjadi haknya dan tanggung jawab dalam rangka mencapai tujuan organisasi. Kejelasan wewenang dan tanggung jawab setiap orang dalam suatu organisasi akan mendukung kinerja karyawan tersebut 
3. Disiplin. Secara umum, displin menunjukkan suatu kondisi atau sikap hormat pada diri karyawan terhadap peraturan dan ketetapan perusahaan. Displin meliputi ketaatan dan hormat terhadap perjanjian yang dibuat antara perusahaan dan pegawai.

4. Inisiatif. Inisiatif seseorang berkaitan dengan daya pikir, kreativitas dalam bentuk ide untuk merencanakan sesuatu yang berkaitan dengan tujuan organisasi. Setiap inisiatif sebaiknya mendapat perhatian atau tanggapan positif dari atasan, kalau memang dia atasan yang baik.

Kinerja juga memiliki dimensi yang dapat menunjang kinerja karyawan dalam mencapai tujuan organisasi. Dimensi dalam hal ini memiliki pengaruh yang kuat terhadap objek yang akan diteliti. Bila dipakai secara baik dapat mempercepat pencapaian tujuan bagu organisasi. Menurut John Miner dalam Fahmi (2017), untuk mencapai atau menilai kinerja, ada dimensi yang menjadi tolak ukur, yaitu :

1. Kualitas, yaitu tingkat kesalahan, kerusakan, kecermatan.

2. Kuantitas, yaitu jumlah pekerjaan pekerjaan yang dihasilkan.

3. Penggunaan waktu dalam kerja

4. Kerja sama dengan orang lain dalam bekerja

Dalam suatu organisasi terdapat indikator kinerja yang dapat menjadi sumber acuan dari kinerja karyawan. Menurut Sedarmayanti (2014) indikator kinerja adalah ukuran kuantitatif dan/atau kualitatif yang menggambarkan tingkat pencapaian suatu sasaran atau tujuan yang telah ditetapkan. Indikator kinerja harus merupakan sesuatu yang akan dihitung dan diukur serta digunakan sebagai dasar untuk menilai atau melihat tingkat kinerja, baik dalam tahap perencanaan, pelaksanaan, maupun kegiatan selesai dan berfungsi. Ada lima persyaratan yang harus dipenuhi dalam melakukan penilaian kinerja agar memperoleh hasil yang efektif menurut Cascio (2013), yaitu: (1) Reliability, (2) Relevance, (3) Sensitivity, (4) Practicality, dan (5) Acceptability.

Berdasarkan syarat-syarat efektivitas sistem penilaian kinerja yang telah di kemukakan diatas, dapat disimpulkan bahwa efektivitas sistem penilaian kinerja karyawan harus memenuhi syarat, yaitu ada kesesuaian antara hasil pekerjaan dan tujuan yang telah ditetapkan lebih dahulu.

\section{Teori Motivasi}

Menurut Hamzah (2014) memberikan definisi motivasi kerja sebagai kekuatan dalam diri orang yang mempengaruhi arah, intensitas dan ketekunan perilaku sukarela seseorang untuk melakukan pekerjaan. Sedangkan menurut Robbert dan Jackson (2012) motivasi kerja merupakan keinginan untuk bertindak. Setiap orang dapat termotivasi oleh beberapa kekuatan yang berbeda. Motivasi kerja adalah hasil dari kumpulan kekuatan internal dan eksternal yang menyebabkan pekerjaan memilih jalan bertindak yang sesuai dan menggunakan prilaku tertentu. Motivasi pada umumnya berkaitan dengan tujuan, sedangkan tujuan organisasional mencangkup pada prilaku yang berkaitan dengan pekerjaan.

Dari pengertian maupun definisi motivasi kerja para ahli di atas maka dapat disimpulkan bahwa motivasi kerja merupakan suatu keadaan atau kondisi yang mendorong, merangsang atau menggerakkan seseorang untuk melakukan sesuatu atau kegiatan yang dilakukannya sehingga ia dapat mencapai tujuannya. Menurut Wibowo (2014) melihat sebagai dorongan motivasi kerja bersumber pada penelitian Mc Celland yang memfokus pada dorongan untuk :

1. Achievement Motivation. Motivasi berprestasi adalah suatu dorongan yang dimiliki banyak orang untuk mengejar dan mencapai tujuan menantang. 
2. Affiliation Motivation. Motivasi untuk berafiliasi merupakan suatu dorongan untuk berhubungan dengan orang atas dasar social, bekerja dengan orang yang cocok dan berpengalaman dengan perasaan sebagai komunitas.

3. Power Motivation. Motivasi akan kekuasaan merupakan suatu dorongan untuk mempengaruhi orang, melakukan pengawasan dan merubah situasi.

Manajer harus membuat penghargaan ekstrinsik pada pekerja. Ada tiga hal yang perlu dipertimbangkan :

1. Menejer perlu memastikan bahwa tujuan kinerja diarahkan pada pencapaian hasil akhir yang besar.

2. Janji peningkatan reward tidak akan memperbaiki usaha lebih besar dan kinerja baik kecuali reward dikaitkan dengan jelas dengan kinerja dan cukup besar untuk mendapatkan kepentingan pekerja.

3. Motivasi dipengaruhi oleh persepsi pekerja tentang kejujuran alokasi reward.

Hamzah (2014:111) mengemukakan bahwa indikator motivasi adalah :

a. Tanggung jawab dalam melakukan pekerjaan. Tanggung jawab merupakan suatu sikap yang timbul untuk siap dan menerima suatu kewajiban atau tugas yang diberikan.

b. Prestasi yang dicapai. Pencapaian prestasi yaitu kemampuan untuk mencapai hasil yang baik secara kualitas maupun kuantitas yang dihasilkan oleh suatu Karyawan tersebut.

c. Pengembangan diri. Pengembangan merupakan suatu proses atau cara untuk mengembangkan sesuatu yang sudah ada.

d. Kemandirian dalam bertindak. Prilaku yang muncul didalam diri untuk bertindak tanpa menyusahkan orang lain

\section{Komitmen Organisasi}

Konsep komitmen organisasional berkaitan dengan tingkat keterlibatan orang dengan organisasi dimana mereka bekerja dan tertarik untuk tetap tinggal dalam organisasi tersebut. Menurut Luthas dalam Wibowo (2014) komitmen organisasi sering didefinisikan sebagai :

a. Sebuah keinginan kuat untuk tetap menjadi anggota organisasi tersebut.

b. Keinginan untuk mendesak usaha pada tingkat tinggi atas nama organisasi.

c. Keyakinan yang pasti dalam dan penerimaan atas nilai-nilai dan tujuan organisasi.

Dari pengertian maupun definisi komitmen organisasi dari para ahli di atas maka dapat disimpulkan bahwa komitmen organisasi adalah suatu sikap yang mencerminkan loyalitas pekerja pada organisasi dan merupakan suatu proses yang sedang berjalan melalui mana peserta organisasi menyatakan perhatian mereka terhadap organisasi dan kelanjutan keberhasilan dan kesejahteraan. Wibowo (2014) mengemukakan bahwa terdapat dua dimensi utama komitmen organisasional, yaitu:

1. Rational Commitment, mencernminkan bahwa pekerjaan memberikan pelayanan pada kepentingan financial, pengembangan dan professional individu.

2. Emmotional Commitment, mencerminkan perasaan bahwa apa yang dilakukan seseorang adalah penting, berharga dan memberikan manfaat nyata bagi orang lain.

Dimensi komitmen organisasi menurut Luthans (2011) adalah :

a. Affective Commitment, menyangkut pada keterkaitan emosional pekerjaan pada identifikasi dengan dan pelibatan dalam organisasi.

b. Continuence Commitment, menyangkut komitmen berdasarkan pada biaya yang bersangkutan dengan pekerjaan dengan meninggalkan organisasi. 
c. Normative Commitment, menyangkut perasaan pekerja atas kewajiban untuk tetap tinggal dengan organisasi karena itu merupakan yang terbaik untuk dilakukan.

\section{Review Penelitian Terdahulu}

Rachmawati Tus Sholikhah, (2017) melakukan penelitian dengan judul Pengaruh Motivasiterhadap Kinerja Karyawan Dengan Komitmen Organisasisebagai Variabel Intervening Pada PT Terminal Teluk Lamong. Hasil penelitian ini motivasi kerja memberikan pengaruh positif dan signifikan terhadap kinerjakaryawan. Hal ini menunjukan bahwa semakin tinggimotivasi kerja yang diberikan perusahaan, maka akan meningkat pula kinerja karyawan tetap generasi Y pada PT Terminal Teluk Lamong. Motivasi kerja memberikan pengaruh positif namun tidak signifikan terhadap komitmen organisasi karyawan. Hal ini menunjukan bahwa motivasi kerja karyawan tidak berpengaruh terhadap komitmen organisasi karyawan tetap generasi Y pada PT Terminal Teluk Lamong. Komitmen organisasi karyawan memberikan pengaruh positif namun tidak signifikan terhadap kinerja karyawan. Hal ini menunjukan bahwa komitmen organisasi karyawan tidak berpengaruh terhadap kinerja karyawan.

Komitmen organisasi tidak dapat menjadi perantara untuk pengaruh motivasi kerja terhadap kinerja karyawan. Hal ini dikarenakan hasil dari nilai koefisien pengaruh tidak langsung lebih kecil daripengaruh langsung. Nasri (2019), Pengawasan Dan Motivasi Terhadap Kinerja Dengan Komitmen Sebagai Variabel Intervening Pada RSUD Muaradua Oku Selatan. Hasil analisis data menunjukkan adanya pengaruh positif dan signifikan budaya organisasi terhadap kinerja karyawan. Adanya pengaruh positif dan signifikan displin kerja terhadap kinerja karyawan. Ada pengaruh positif dan signifikan komunikasi terhadap kinerja karyawan. Dan ada pengaruh positif dan signifikan budaya organisasi, displin kerja, komunikasi interpersonal secara simultan terhadap kinerja karyawan PT Adidaya Bima Perkasa Yogyakarta.

\section{Hipotesis}

Hipotesis penelitian ini adalah diduga motivasi berpengaruh signifikan terhadap komitmen organisasi, diduga motivasi berpengaruh signifikan terhadap kinerja karyawan pada UPT Sungai Duku Pekanbaru dan Diduga komitmen organisasi berpengaruh signifikan terhadap kinerja pada UPT Sungai Duku Pekanbaru.

\section{Model Penelitian}

Model penelitian ini adalah :

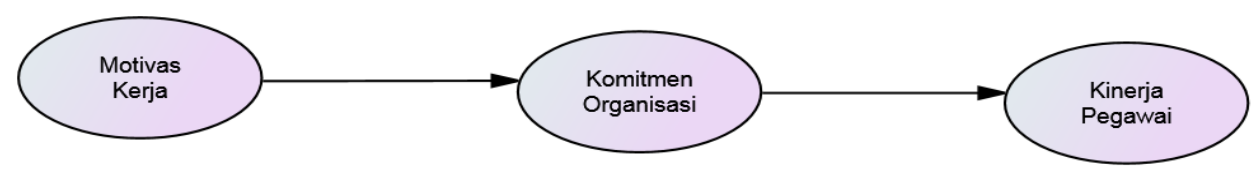

\section{Definisi Operasional Variabel Penelitian}

Definisi operasional variabel penelitian ini dapat dilita pada Tabel 1.

Tabel 1: Definisi Operasional Variabel Penelitian

\begin{tabular}{|c|c|c|c|}
\hline Variabel & Definisi & Indikator & Skala \\
\hline Kinerja $\left(\mathrm{Y}_{2}\right)$ & $\begin{array}{l}\text { Kinerja adalah hasil kerja } \\
\text { karyawan dilihat dari aspek } \\
\text { kualitas, kuantitas, waktu kerja, } \\
\text { dan kerja sama untuk mencapai } \\
\text { tujuan yang telah ditetapkan oleh }\end{array}$ & $\begin{array}{l}1 . \quad \text { Kualitas, yaitu tingkat } \\
\text { kesalahan, kerusakan, kecermatan. } \\
\text { 2. } \quad \text { Kuantitas, yaitu jml } \\
\text { pekerjaan pekerjaan yang dihasilkan. } \\
\text { 3. } \quad \text { Penggunaan waktu dalam } \\
\text { kerja, yaitu tingkat ketidakhadiran, }\end{array}$ & Ordinal \\
\hline
\end{tabular}




\begin{tabular}{|c|c|c|c|}
\hline & $\begin{array}{l}\text { organisasi (Menurut Sutrisno, } \\
\text { 2016:172) }\end{array}$ & $\begin{array}{l}\text { keterlambatan, waktu } \\
\text { efektif/jam kerja hilang. } \\
\text { 4. Kerja sama dgn orang } \\
\text { laindalam bekerja }\end{array}$ & \\
\hline Motivasi (X) & $\begin{array}{l}\text { Motivasi kerja merupakan } \\
\text { sekumpulan kekuatan energitik } \\
\text { yang mulai baik dari dalam } \\
\text { maupun diluar pekerja, dimulai } \\
\text { dari usaha yang berkaitan dengan } \\
\text { pekerjaan, mempertimbangkan } \\
\text { arah, intensitas dan ketekunannya } \\
\text { (Wibowo, 2014:127) }\end{array}$ & 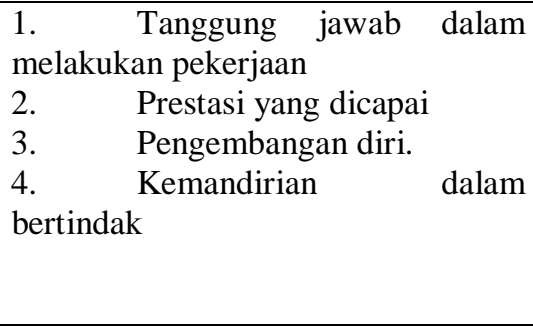 & Ordinal \\
\hline $\begin{array}{l}\text { Komitmen } \\
\text { Organisasi } \\
\left(\mathrm{Y}_{1}\right)\end{array}$ & $\begin{array}{l}\text { Komitmen organisasi mrpakan } \\
\text { suatu tingkatan dimana individu } \\
\text { mengidentivikasi dan terlibat } \\
\text { dengan organisasinya dan atau } \\
\text { tidak ingin meninggalkannya } \\
\text { (Wibowo, 2014:187) }\end{array}$ & $\begin{array}{l}\text { Affective Commitment } \\
\text { Continuence Commitment } \\
\text { Normative Commitment }\end{array}$ & Ordinal \\
\hline
\end{tabular}

\section{METODOLOGI PENELITIAN}

Penelitian ini dilakukan pada UPT Pelabuhan Sungai Duku yang terletak di pinggir terletak di tepi Sungai Siak. Penelitian dilakukan selama 4 (empat) bulan yang akan dimulai pada Bulan April 2021 sampai Bulan Agustus 2021. Jenis dan sumber data yang digunakan dalam penelitian ini terdiri dari data primer dan data sekunder. Teknik pengumpulan data yang digunakan yaitu kuesioner, wawancara dan file riset. Populasi penelitian ini adalah seluruh karyawan UPT Pelabuhan Sungai Duku yang berjumlah sebanyak 73 pegawai dan seluruhnya dijadikan sampel, dengan demikian teknik pengambilan sampel dilakjkan dengan metode sampel. Analisa data dilakukan dengan dengan uji validitas dan reliabilitas selanjutnya dilanjutkan dengan pengujian hipotesis. Model penelitian yang akan digunakan dalam penelitian ini adalah model struktur berjenjang dan untuk menguji hipotesis yang diajukan digunakan teknik analisis SEM (Structural Equation Modelling) yang dioperasikan melalui program Smart PLS Versi 3.00. Setelah teori atau model teoritis dikembangkan dan digambarkan dalam sebuah diagram alur, peneliti dapat mulai mengkonversikan spesifikasi model tersebut ke dalam rangkaian persamaan struktural sebagai berikut:

$\mathrm{Y} 1=\beta_{1} \mathrm{X}_{1}+\mathrm{Z}_{1}$ dan $\mathrm{Y} 2=\beta_{2} \mathrm{X}_{1}+\beta_{3} \mathrm{X}_{1} \mathrm{Y}_{1}+\mathrm{Z}_{2}$

Keterangan : $Y_{1}=$ Komitmen Organisasi, $Y_{2}=$ Kinerja Karyawan, $X_{1}=$ Motivasi $\beta_{1}-\beta_{3}=$ Koefisien Regresi

Pemilihan metode PLS dalam analisis data pada penelitian ini didasarkan bahwa dalam penelitian ini terdapat tiga variabel yang dibentuk dengan indikator formatif dan membentuk efek moderating. Model formatif mengasumsikan bahwa konstruk atau variabel laten mempengaruhi indikator, dimana arah hubungan kausalitas dari konstruk ke indicator menifges (Ghazali, 2006). Pendugaan parameter dalam PLS meliputi 3 hal yaitu :

1. Weight estimate yang digunakan untuk menciptakan skor variabel laten.

2. Estimasi jalur (path estimate) yang menghubungan antar variabel later dan estimasi loading antara variabel laten dengan indikatornya.

3. Means dan lokasi parameter (nilai konstanta, regresi dan intersep untuk indikator dan variabel laten.

Untuk memperoleh ketiga estimasi ini, PLS menggunakan iterasi tiga tahap dan setiap tahan iterasi menghasilkan estimasi. Tahap pertama menghasilkan penduga bobot 
(weight estimate), tahap kedua menghasilkan estimasi means dan lokasi (konstanta). Pada dua tahap pertama proses iterasi dilakukan dengan pendekatan devuasu (penyimpangan) dari nilai meas (rata-rata). Pada tahap ketiga, estimasi bida didasrkan pada matriks data asli atau hasil penduga bobot dan koesfisien jalur pada tahap kedua, tujuannya untuk menghitung dan lakasi parameter (Ghazali, 2011). Berikut langkah-langkah dalam analisis dengan partial leasm square, (Yamin, 2011) :

1. Langkag pertama : merancang model strukturak (inner model). Pada tahap ini, peneliti memformasikan model hubungan antar konstrak.

2. Langkah kedua, merancang model pengukuran (outer model). Pada tahap ini peneliti mendefinisikan dan menspesifikasi hubungan antara konstrak later dengan indicatornya apakah bersifat reflektif atau formatif.

\section{Gambar 1 : Model Penelitian}

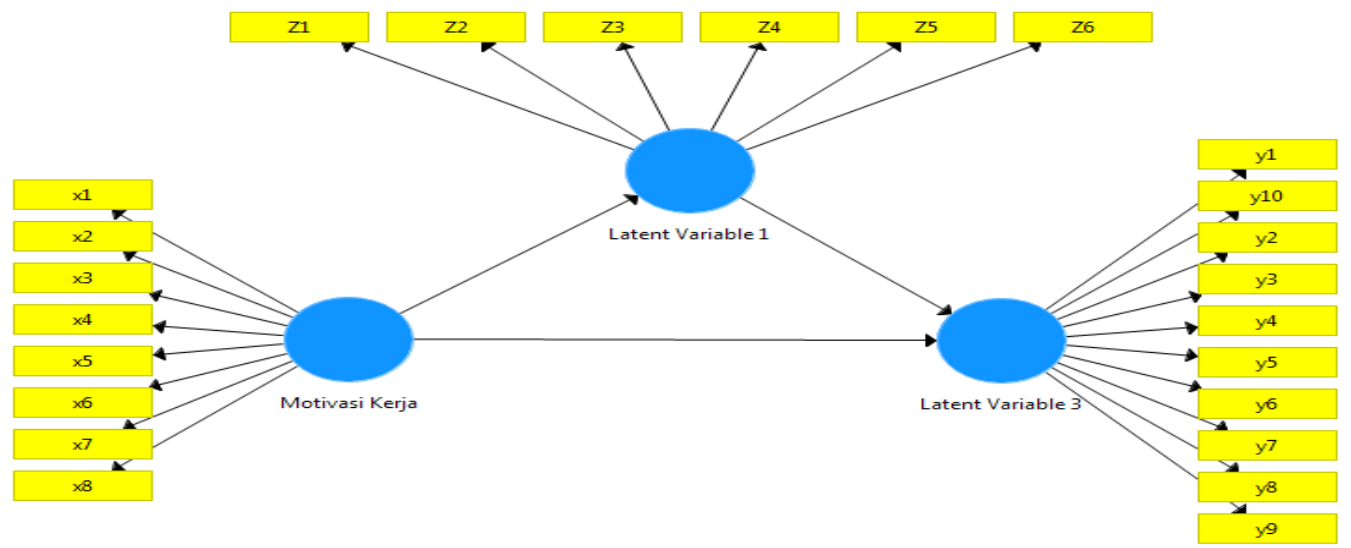

3. Langkah ketiga: mengkonstruksi diagram jalur.

4. Langkah ke empat: estimasi model. Pada langkah ini tiga skema pemilihan weighting dalam proses setimasi model, yaitu factor weighting scheme, centroid weighting scheme dan path weighting scheme.

5. Langkah kelima: goodness of fit atau evaluasi model meliputi evaluasi model pengukuran dan evaluasi model structural.

6. Langkag ke enam, pengujian hipotesis dan interprestasi.

Berikut adalah kriteria penilaian model PLS yang digunakan oleh Chin 1998 dalam Ghazali (2011).

Tabel 2: Kriteria Penilaian PLS

\begin{tabular}{|c|c|}
\hline Kriteria & Penjelasan \\
\hline \multicolumn{2}{|r|}{ Evaluasi Model Struktural } \\
\hline $\mathrm{R}^{2}$ untuk variabel endogen & $\begin{array}{l}\text { Hasil } \mathrm{R}^{2} \text { sebesar } 0.67,0.33 \text { dan } 0.19 \text { untuk variabel endogen dalam } \\
\text { model strukturan mengindentifikasi bahwa moder "baik" , } \\
\text { "moderat" dan "lemah". }\end{array}$ \\
\hline Estimasi koefisien jalur & $\begin{array}{l}\text { Nilai estimasi untuk hubungan jalur dalam model structural harus } \\
\text { signifikan. Nilai signifikan ini dapat diperoleh dengan prosedur } \\
\text { bootstrapping. }\end{array}$ \\
\hline $\mathrm{F}^{2}$ untuk effect size & $\begin{array}{l}\text { Nilai } \mathrm{f}^{2} \text { sebesar } 0.2,0.15 \text { dan } 0.35 \text { dapat diinterprestasikan apakah } \\
\text { prediktor vaeiabel later mempunyai pengaruh yang lemah, medium } \\
\text { atau besar pada tingkat stuktural }\end{array}$ \\
\hline \multicolumn{2}{|r|}{ Evaluasi model pengukuran reflective } \\
\hline Loading factor & Nilai loading factor 0.70 \\
\hline Composite Reliability & $\begin{array}{l}\text { Composite reliability mengukur internal consistency dan nilainya } \\
\text { harus diatas } 0.60\end{array}$ \\
\hline Average Variances Extr & Nilai Average Variances Extracted (AVE) harus diatas 0.5 \\
\hline
\end{tabular}




\begin{tabular}{|l|l|}
\hline Validitas Deskriminan & $\begin{array}{l}\text { Nilai akar kuadrat dari AVE harus lebih besar dari pada nilai korelasi } \\
\text { antar variabel later. }\end{array}$ \\
\hline Cross loading & $\begin{array}{l}\text { Merupakan ukuran lain dari validitas diskriminan. Diharapkan } \\
\text { disetiap blok indikator memiliki loading lebih tinggi untuk setiap } \\
\text { variabel laten yang diukur di bandingkan dengan indikator untuk } \\
\text { laten variabel lainnya. }\end{array}$ \\
\hline Evaluasi Model Pengukuran Fromatif \\
\hline Signifikansi nilai weight & $\begin{array}{l}\text { Nilai estimasi untuk model pengukuran formatif haris signifikan. } \\
\text { Tingkat signifikansi dinilai dengan prosedur bootstrepping }\end{array}$ \\
\hline Multicolineritas & $\begin{array}{l}\text { Variabel manifest dalam blok harus diuji apakah terdapat multkol. } \\
\text { Nilai variance inflation factor (VIF) dapat digunakan untuk menguki } \\
\text { hal ini. Nilai VIF diatas 10 mengindikaisikan terdapat multikol. }\end{array}$ \\
\hline
\end{tabular}

\section{HASIL PENELITIAN}

Sebelum melakukan analisis data, maka perlu dilakukan beberapa tahapan pengujian, yaitu :

\section{Pengujian Outer Model (Model Pengukuran)}

Model penelitian ini akan dianalisis menggunakan metode Partial Least Square (PLS) dan dibantu dengan Software Smart PLS 3.0. PLS merupakan salah satu metode alternatif Structural Equation Modeling (SEM) yang dapat dilakukan untuk mengatasi permasalahan pada hubungan diantara variabel yang sangat kompleks tetapi ukuran sampel data kecil (dan memiliki asumsi non parametrik, artinya bahwa data tidak mengacu pada salah satu distibusi tertentu (Yamin dan Kurniawan, 2009).

\section{a. Convergent Validity}

Convergent Validity dilakukan dengan melihat item reliability (indikator validitas) yang ditunjukkan oleh nilai loading factor. Loading factor adalah angka yang menunjukkan korelasi antara skor suatu item pertanyaan dengan skor indikator konstrak indikator yang mengukur konstrak t ersebut. Nilai loading factor lebih besar 0,7 dikatakan valid. Dalam penelitian ini batas loading factor yang digunakan sebesar 0,7. Setelah dilakukan pengolahan data dengan menggunakan SmartPLS 3.0 hasil loading factor dapat ditunjukkan seperti pada Tabel 3 :

Tabel 3: Nilai Loading Factor Iterasi Pertama

\begin{tabular}{|l|c|c|}
\hline Variabel & Indikator & Outer Loading \\
\hline Kinerja & K1 & 0.612 \\
& K2 & 0.707 \\
& K3 & 0.747 \\
& K4 & 0.531 \\
& K5 & 0.639 \\
& K6 & 0.618 \\
& K7 & 0.597 \\
& K8 & 0.601 \\
& K9 & 0.731 \\
\hline Motivasi & K10 & 0.812 \\
& M2 & 0.790 \\
& M3 & 0.875 \\
& M4 & 0.840 \\
& M5 & 0.782 \\
& M6 & 0.874 \\
& & 0.869 \\
\hline
\end{tabular}




\begin{tabular}{|l|c|c|}
\hline & M7 & 0.704 \\
& M8 & -0.285 \\
\hline Komitmen & KO1 & 0.854 \\
Organisasi & KO2 & 0.936 \\
& KO3 & 0.921 \\
& KO4 & 0.949 \\
& KO5 & 0.913 \\
& KO6 & 0.777 \\
\hline
\end{tabular}

\section{Sumber : Hasil Pengolahan Data, 2021}

Dari hasil pengolahan data dengan SmartPLS yang ditunjukkan pada Tabel 3, bahwa mayoritas indikator pada masing-masing variabel dalam penelitian ini memiliki nilai loading factor yang lebih besar dari 0,70 dan dikatakan valid. Selain itu ada 6 indikator yang memiliki nilai loading factor kurang dari 0,70 yaitu pertama pada variabel kinerja sebanyak lima indikator dan variabel komitmen oranginisasi sebanyak satu indikator. Hal ini menunjukkan bahwa indikator variabel yang memiliki nilai loading factor lebih besar dari 0,70 memiliki tingkat validitas yang tinggi, sehingga memenuhi convergent validity. Sedangkan indikator variabel yang memiliki nilai loading factor lebih kecil dari 0,70 memiliki tingkat validitas yang rendah sehingga indikator variabel tersebut perlu dieliminasi atau dihapus dari model. Nilai loading factor setelah indikator dari variabel kinerja dan komitmen organisasi khusus K1, K4, K5, K7 dan K10 serta M8 dieliminasi dapat ditunjukkan pada Tabel 4

Tabel 4 : Nilai Loading Faktor Iterasi Kedua

\begin{tabular}{|l|c|c|}
\hline Variabel & Indikator & Outer Loading \\
\hline Kinerja & K2 & 0.750 \\
& K3 & 0.736 \\
& K6 & 0.586 \\
& K8 & 0.678 \\
Kotivasi & M1 & 0.784 \\
& M2 & 0.791 \\
& M3 & 0.889 \\
& M4 & 0.846 \\
& M5 & 0.793 \\
& M6 & 0.876 \\
& M7 & 0.868 \\
Komitmen & KO1 & 0.698 \\
Organisasi & KO3 & 0.855 \\
& KO4 & 0.943 \\
& KO5 & 0.921 \\
& KO6 & 0.949 \\
& KO & 0.913 \\
& Kata 201 & 0.774 \\
\hline
\end{tabular}

\section{Sumber : Hasil Pengolahan Data, 2021}

Berdasarkan Tabel 4 menunjukkan bahwa terjadi peningkatan nilai loading factor untuk indikator-indikator pada variabel kinerja dan motivasi kerja dieliminasi dan dilakukan perhitungan kembali.

\section{c. Discriminant Validity}


Discriminant Validity dilakukan dengan cara melihat nilai cross loading pengukuran konstrak. Nilai cross loading menunjukkan besarnya korelasi antara setiap konstrak dengan indikatornya dan indikator dari konstrak blok lainnya. Suatu model pengukuran memiliki discriminant validity yang baik apabila korelasi antara konstrak dengan indikatornya lebih tinggi daripada korelasi dengan indikator dari konstrak blok lainnya. Setelah dilakukan pengolahan data dengan menggunakan SmartPLS 3.0 hasil cross loading. Dari hasil cross loading menunjukkan bahwa nilai korelasi konstrak dengan indikatornya lebih besar dari pada nilai korelasi dengan konstrak lainnya. Dengan demikian bahwa semua konstrak atau variabel laten sudah memiliki discriminant validity yang baik, dimana indikator pada blok indikator konstrak tersebut lebih baik daripada indikator di blok lainnya. Evaluasi selanjutnya, yaitu dengan membandingkan nilai akar AVE dengan korelasi antar konstrak. Hasil yang direkomendasikan adalah nilai akar AVE harus lebih tinggi dari korelasi antar konstrak (Yamin dan Kurniawan, 2011). Model memiliki discriminant validity yang lebih baik apabila akar kuadrat AVE untuk masingmasing konstrak lebih besar dari korelasi antara dua konstrak di dalam model. Nilai AVE yang baik disyaratkan memiliki nilai lebih besar dari 0,50. Dalam penelitian ini, nilai AVE dan akar kuadrat AVE untuk masing-masing konstrak dapat ditunjukkan pada Tabel 5 :

Tabel 5 : Nilai AVE dan Akar Kuadrat AVE

\begin{tabular}{|l|c|c|c|c|}
\hline & Cronbach's Alpha & rho_A & $\begin{array}{c}\text { Composite } \\
\text { Reliability }\end{array}$ & $\begin{array}{c}\text { Average } \\
\text { Variance } \\
\text { Extracted (AVE) }\end{array}$ \\
\hline Kinerja & 0.766 & 0.786 & 0.834 & 0.504 \\
\hline Komitmen Organisasi & 0.949 & 0.957 & 0.959 & 0.798 \\
\hline Motivasi Kerja & 0.921 & 0.926 & 0.937 & 0.681 \\
\hline
\end{tabular}

Sumber : Hasil Pengolahan Data, 2021

Berdasarkan Tabel 5 semua konstrak menunjukkan nilai AVE yang lebih besar dari 0,500 yaitu dengan nilai terkecil 0,504 untuk variabel kinerja dan terbesar 0,798 untuk variabel komitmen organisasi. Nilai tersebut sudah memenuhi persyaratan sesuai dengan batas nilai minimum AVE yang ditentukan yaitu 0,50. Setelah diketahui nilai akar kuadrat dari AVE untuk masing-masing konstrak, tahap selanjutnya adalah membandingkan akar kuadrat AVE dengan korelasi antar konstrak dalam model. Pada penelitian ini hasil dari korelasi antar konstrak dengan nilai akar kuadrat AVE dapat ditunjukkan pada Tabel 6 berikut:

Tabel 6 : Nilai Korelasi antar Konstrak dan Nilai Akar Kuadrat AVE

\begin{tabular}{|l|r|r|r|}
\hline & \multicolumn{1}{|l|}{ KInerja } & Komitmen Organisasi & Motivasi Kerja \\
\hline Kinerja & 0.710 & & \\
\hline Komitmen Organisasi & 0.435 & 0.894 & \\
\hline Motivasi Kerja & 0.489 & 0.348 & 0.825 \\
\hline
\end{tabular}

\section{Sumber : Hasil Pengolahan Data, 2021}

Dari Tabel 6 menunjukkan bahwa nilai akar kuadrat AVE untuk masing-masing konstrak lebih besar dari pada nilai korelasinya sehingga konstrak dalam model penelitian ini masih dapat dikatakan memiliki discriminant validity yang baik.

\section{d. Composite Reliability}


Outer model selain diukur dengan menilai convergent validity dan discriminant validity juga dapat dilakukan dengan melihat reliabilitas konstrak atau variabel laten yang diukur dengan nilai composite reliability. Konstrak dinyatakan reliabel jika composite reliability mempunyai nilai > 0.7 , maka konstrak dinyatakan reliabel. Hasil output SmartPLS untuk nilai composite reliability dapat ditunjukkan pada Tabel 7:

Tabel 7 : Nilai Composite Reliability

\begin{tabular}{|l|c|c|}
\hline & Cronbach's Alpha & Composite Reliability \\
\hline Kinerja & 0.766 & 0.834 \\
\hline Komitmen Organisasi & 0.949 & 0.959 \\
\hline Motivasi Kerja & 0.921 & 0.937 \\
\hline
\end{tabular}

\section{Sumber : Hasil Pengolahan Data, 2021}

Dari hasil output SmartPLS pada Tabel 7 menunjukkan nilai composite reliability untuk semua konstrak berada diatas nilai 0,70 . Dengan nilai yang dihasilkan tersebut, semua konstrak memiliki reliabilitas yang baik sesuai dengan batas nilai minumun yang telah disyaratkan.

\section{d. Pengujian Inner Model (Model Struktural)}

Setelah pengujian outer model yang telah memenuhi, berikutnya dilakukan pengujian inner model (model structural). Inner model dapat dievaluasi dengan melihat r-square (reliabilitas indikator) untuk konstrak dependen dan nilai t-statistik dari pengujian koefisien jalur (path coefficient). Semakin tinggi nilai r-square berarti semakin baik model prediksi dari model penelitian yang diajukan. Nilai path coefficients menunjukkan tingkat signifikansi dalam pengujian hipotesis.

\section{Analisis Variant $\left(\mathbf{R}^{2}\right)$ atau Uji Determinasi}

Analisis Variant $\left(\mathrm{R}^{2}\right)$ atau Uji Determinasi yaitu untuk mengetahui besar pengaruh variabel independen terhadap variabel dependen tersebut, nilai dari koefisien determinasi dapat ditunjukkan pada Tabel 8:

Tabel 8: Nilai R-square

\begin{tabular}{|l|c|c|}
\hline & R Square & R Square Adjusted \\
\hline Motivasi & 0.819 & 0.671 \\
\hline Komitmen Organisasi & 0.721 & 0.519 \\
\hline
\end{tabular}

\section{Sumber: Hasil Pengolahan Data, 2021}

Berdasarkan nilai r-square pada Tabel 8 menunjukkan bahwa motivasi dan komitmen organisasi mampu menjelaskan variabilitas konstrak kinerja sebesar $67.1 \%$, dan sisanya sebesar $32.9 \%$ diterangkan oleh konstrak lainnya diluar yang diteliti dalam penelitian ini. Sedangkan motivasi mampu menjelaskan variabilitas konstrak komitmen organisasi $51.9 \%$, dan sisanya sebesar $48.1 \%$ diterangkan oleh konstrak lainnya diluar yang diteliti dalam penelitian ini.

\section{Pengujian Hipotesis}

Pengujian Hipotesis dilakukan berdasarkan hasil pengujian Inner Model (model struktural) yang meliputi output r-square, koefisien parameter dan t-statistik. Untuk melihat apakah suatu hipotesis itu dapat diterima atau ditolak diantaranya dengan memperhatikan nilai signifikansi antar konstrak, t-statistik, dan p-values. Pengujian 
hipotesis penelitian ini dilakukan dengan bantuan software SmartPLS (Partial Least Square) 3.0. Nilai-nilai tersebut dapat dilihat dari hasil bootstrapping. Rules of thumb yang digunakan pada penelitian ini adalah t-statistik $>1,96$ dengan tingkat signifikansi pvalue $0,05(5 \%)$ dan koefisien beta bernilai positif. Nilai pengujian hipotesis penelitian ini dapat ditunjukan pada Tabel 8 dan untuk hasil model penelitian ini dapat digambarkan seperti tampak pada Gambar 2:

\section{Gambar 2 : Hasil Model Penelitian}

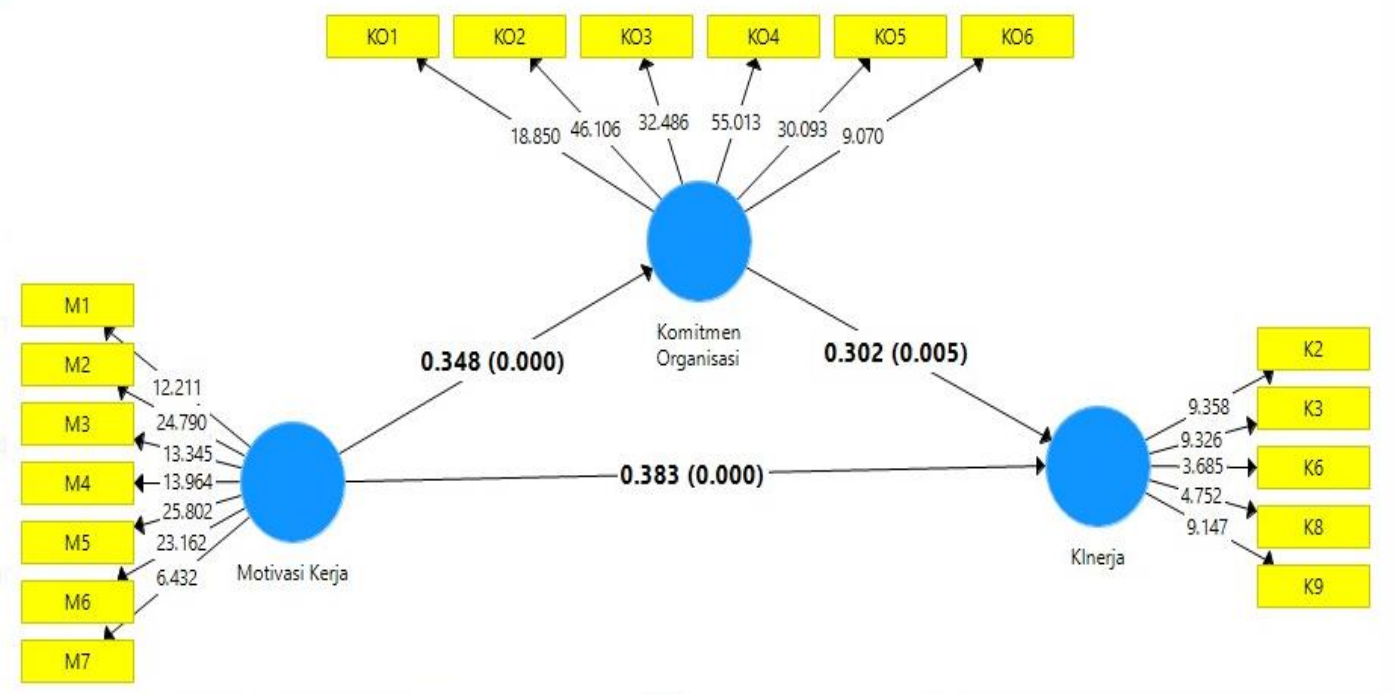

Sumber : Hasil Pengolahan Data, 2021

Tabel 9 : Hasil Path Coefficients

\begin{tabular}{|l|c|c|c|c|c|}
\hline & $\begin{array}{c}\text { Original } \\
\text { Sample } \\
(\mathbf{O})\end{array}$ & $\begin{array}{c}\text { Sample } \\
\text { Mean } \\
\text { (M) }\end{array}$ & $\begin{array}{c}\text { Standard } \\
\text { Deviation } \\
\text { (STDEV) }\end{array}$ & $\begin{array}{c}\text { T Statistics } \\
(\mid \mathbf{O} / \text { STDEV|) }\end{array}$ & P Values \\
\hline $\begin{array}{l}\text { Komitmen Organisasi -> } \\
\text { Kinerja }\end{array}$ & 0.302 & 0.303 & 0.107 & 2.832 & 0.005 \\
\hline Motivasi Kerja -> KInerja & 0.383 & 0.392 & 0.093 & 4.141 & 0.000 \\
\hline $\begin{array}{l}\text { Motivasi Kerja -> } \\
\text { Komitmen Organisasi }\end{array}$ & 0.348 & 0.359 & 0.079 & 4.391 & 0.000 \\
\hline
\end{tabular}

\section{Sumber : Hasil Pengolahan Data, 2021}

Hipotesis pertama menguji apakah motivasi berpengaruh signifikan terhadap komitmen organisasi pada UPT Pelabuhan Sungai Duku Pekanbaru. Hasil pengujian menunjukkan nilai koefisien beta motivasi kerja terhadap komitmen organisasi sebesar 0.348 dan t-statistik yaitu sebesar 4.391 dan p-values sebesar 0.000. Hasil pengujian membuktikan ada pengaruh yang signifikan, sehingga hipotesis pertama diterima. Hal tersebut membuktikan bahwa motivasi kerja terbukti memiliki pengaruh positif terhadap komitmen organisasi. Hipotesis kedua menguji apakah motivasi berpengaruh signifikan terhadap kinerja pada UPT Pelabuhan Sungai Duku Pekanbaru. Hasil pengujian menunjukkan nilai koefisien beta motivasi terhadap kinerja sebesar 0,383 dan t-statistik yaitu sebesar 4.414 dan p-values sebesar 0.000. Dari hasil ini dinyatakan p-value lebih rendah dari alpha yaitu $0.000<0.05$. Hal ini membuktikan bahwa motivasi kerja berpengaruh signifikan terhadap kinerja pegawai pada UPT Pelabuhan Sungai Duku Pekanbaru. Hipotesis ketiga menguji apakah komitmen organisasi berpengaruh 
signifikan terhadap kinerja karyawan pada UPT Pelabuhan Sungai Duku Pekanbaru. Hasil pengujian menunjukkan nilai koefisien beta komitmen oragnisasi terhadap kinerja sebesar 0.302 dan t-statistik yaitu sebesar 2.832 dan p-values sebesar 0.005. Dari hasil ini dinyatakan p-value lebih rendah dari alpha yaitu $0.005<0.05$. Hal ini membuktikan bahwa komitmen organisasi berpengaruh signifikan terhadap kinerja pegawai pada UPT Pelabuhan Sungai Duku Pekanbaru. Dengan demikian hipotesis ke tiga di terima. Secara ringkas hasil pengujian hipotesis dapat dilihat pada Tabel 10 dibawah ini.

\section{Tabel 10 : Ringkasan Hasil Pengujian Hipotesis}

\begin{tabular}{|c|c|c|c|}
\hline \multicolumn{2}{|r|}{ Hipotesis } & Hasil & Keterangan \\
\hline H1 & $\begin{array}{l}\text { Motivasi berpengaruh signifikan } \\
\text { terhadap komitmen organisasi pada } \\
\text { UPT Sungai Duku Pekanbaru }\end{array}$ & $\begin{array}{l}\beta 1=-0.348 \\
\mathrm{t} \text {-stat }=4.391(0.000)\end{array}$ & Diterima \\
\hline $\mathrm{H} 2$ & $\begin{array}{l}\text { Motivasi berpengaruh signifikan } \\
\text { terhadap kinerja karyawan pada } \\
\text { UPT Sungai Duku Pekanbaru }\end{array}$ & $\begin{array}{l}\beta 2=-0.383 \\
\text { t-stat }=4.141(0.000\end{array}$ & Diterima \\
\hline H3 & $\begin{array}{l}\text { Komitmen organisasi berpengaruh } \\
\text { signifikan terhadap kinerja pada } \\
\text { UPT Sungai Duku Pekanbaru }\end{array}$ & $\begin{array}{l}\beta 3=0.302 \\
\mathrm{t} \text {-stat }=2.832(0.005)\end{array}$ & Diterima \\
\hline
\end{tabular}

\section{Pembahasan}

Pelabuhan merupakan salah satu mata rantai transportasi yang menunjang roda perekonomian negara dan daerah. perindustrian, pertambangan, pertanian dan perdagangan pada umumnya membutuhkan jasa transportasi termasuk jasa pelabuhan sebagai rantai distribusi produk yang dihasilkan. Dengan demikian dapat dilihat bahwa kompleksnya perencanaan suatu pelabuhan, Jika merujuk pada regulasi yang ada terutama UU Kepelabuhanan dan UU Pelayaran, sejatinya UU tersebut telah mensyaratkan timbulnya inovasi dari otoritas pelabuhan khususnya pengembangan Otoritas Pelabuhan untuk mengawasi dan mengelola operasi dagang dalam setiap pelabuhan. Tanggung-jawab utama mereka adalah untuk mengatur, memberi harga dan mengawasi akses ke prasarana dan layanan pelabuhan dasar termasuk daratan dan perairan pelabuhan, alat-alat navigasi, kepanduan (pilotage), pemecah ombak, tempat pelabuhan, jalur laut (pengerukan) dan jaringan jalan pelabuhan.

Di Pelabuhan Sungai Duku terdapat dua buah gedung kantor, gedung yang pertama berfungsi untuk mengawasi jalannya aktfitas kerja di Pelabuhan yang diisi oleh Pegawai Dinas Perhubungan bagian laut atau sungai yang bertugas mengawasi pelaksanaan aktifitas kerja para buruh (Porter) di Pelabuhan. Mereka bertanggung jawab terhadap keberhasilan perwujudan sistem transportasi sungai. Gedung kantor yang kedua yakni terletak di lantai atas juga berfungsi sebagai tempat pengawasan yang diisi dinas perhubungan yang mengawasi turun naiknya para penumpang. Melihat kompleksnya aktivitas di Pelabuhan Sungai Duku Pekanbaru, maka tuntutan terhadap peningkatan kinerja semakin tinggi. Berdasarkan hasil tanggapan karyawan atau pegawai pada UPT Pelabuhan Sungai Duku maka diketahui bahwa mereka sudah memiliki kinerja yang baik. Namun demikian, pihak pimpinan diminta untuk memperhatikan faktor yang mempengaruhi kinerja pegawai tersebut. Karena baik atau buruknya kinerja suatu instansi sangat tergantung pada baik atau buruknya kinerja pegawai dalam instansi tersebut.

Hasil penelitian ini telah membuktikan bahwa berpengaruh signifikan terhadap kinerja pegawai. Ini memberikan arti bahwa jika diamsumsikan motivasi meningkat maka 
kinerja pegawai pada UPT Sungai Duku juga akan meningkat, dan sebaliknya jika diasumsikan motivasi kerja pegawai mengalami penurunan maka kinerja pergawai tersebut juga akan menurun. Hasil penelitian ini tidak sejalan dengan penelitian yang dilakukan oleh Rachmawati (2017), dimana hasil penelitiannya menyimpulan bahwa motivasi kerja memberikan pengaruh positif dan signifikan terhadap kinerja karyawan. Hal ini menunjukan bahwa semakin tinggi motivasi kerja yang diberikan perusahaan, maka akan meningkat pula kinerja karyawan tetap generasi Y pada PT Terminal Teluk Lamong.

Penelitian yang dilakukan oleh Irwan La Mane, dkk, (2020), menyimpulkan bahwa motivasi kerja berpengaruh positif dan signifikan terhadap kinerja pegawai. Arah pengaruh positif berarti bahwa semakin baik motivasi kerja dari pegawai maka kinerja yang dihasilkan akan semakin baik. Motivasi kerja berpengaruh positif dan signifikan terhadap disiplin kerja. Arah pengaruh positif berarti bahwa semakin baik motivasi kerja dari pegawai maka disiplin kerja yang ada akan semakin baik. Disiplin kerja berpengaruh positif dan signifikan terhadap kinerja. Arah pengaruh positif berarti bahwa semakin baik disiplin kerja pegawai maka kinerja yang dihasilkan akan semakin baik.

Hasil ini sesuai dengan tanggapan pegawai untuk variabel motivasi, dimana mereka secara umum memiliki motivasi kerja yang tinggi jika diperhatikan dari tangung jawab pegawai pada pekerjaan yang sudah menjadi tugasnya. Kemudian pegawai pada UPT Pelabuhan Sungai Duku juga termotivasi dalam melaksanakan pekerjaan karena adanya penghargaan yang diberikan oleh pimpinan pada pegawai yang dapat memberikan hasil kerja terbaiknya pada instansi ini. Disamping pihah pimpinan UPT Pelabuhan Sungai Duku juga sudah menjalankan kebijakan pemberikan kesempatan untuk peningkatan karir bagi pegawai.

Kemudian hasil penelitian ini juga membuktikan adanya pengaruh yang signifikan dari motivasi kerja terhadap komitmen organisasi. Artinya semakin baik motivasi kerja pegawai maka akan semakin baik komitmen organisasi pada pegawainya. Komitmen organisasi artinya, adanya pelaksanakan atau penerapan semua kebijakan yang sudah dirumuskan oleh pimpinan dalam melaksanakan aktivitas di isntansi tersebut. Pembuktian adanya pengaruh yang signifikan motivasi kerja pegawai terhadap komitmen organisasi mendukung penelitian yang dilakukan oleh Nurul Qomarianing (2016). Dimana dia menyimpulkan bahwa hasil penelitian menunjukkan Motivasi Kerja berpengaruh signifikan terhadap Komitmen Organisasional dengan nilai koefisien jalur 0.266 dan signifikasi t 0.035 . Motivasi kerja berpengaruh signifikan terhadap Kinerja Karyawan dengan nilai koefisien jalur 0.255dengan signifikan t 0.035.

Hasil penelitian dari fakta lapangan menunjukkan bahwa pemberian motivasi sangatlah penting untuk menunjang kinerja pegawai. Adapun motivasi yang diberikan oleh UPT Pelabuhan Sungai Duku berupa penghargaan dalam upaya untuk memotivasi para karyawan yang berprestasi sebagai bentuk penghargaan dari intansi. Pemberian motivasi oleh UPT Pelabuhan Sungai Duku sangat berperan terhadap karyawan untuk menunjang kinerjanya. Beberapa cara untuk meningkatkan kemampuan kinerja karya wan adalah dengan cara melakukan pelatihan sesuai bidangnya, penambahan wawasan seperti mengadakan pertemuan intesif secara rutin dalam pengarahan tentang bagaimana program kerja yang di jalankan serta pemberian gaji yang sepadan, dengan kinerja yang di tunjukkan oleh pegawai Dengan adanya kemampuan kinerja yang baik maka dapat meningkatkan citra instansi. Adapun beberapa cara memaknai kinerja karyawan apakah sudah baik atau belum yaitu berdasarkan indikator-indikator keberhasilan yang sudah ditetapkan oleh UPT Pelabuhan Sungai Duku. 
Sebagai hasilnya bahwa karyawan tersebut masuk dalam tingkatan kinerja tertentu sehingga dapat dinilai dari beberapa aspek tertentu sebagai berikut: tingkat efektivitas, efesiensi, keamanan dan kepuasan pelanggan atau pihak yang dilayani. Sehingga penyusuaian pekerjaan juga harus diperhatikan dalam instansi karna penyusuaian pekerjaan sangatlah penting bagi para pegawai untuk dapat menjalin hubunggan yang baik dengan lingkungan disekitar pekerjaan. Karena lingkungan bisa menjadi nilai-nilai yang bisa digunakan oleh seorang karyawan untuk mencapai suatu keberhasilan. Dari penjelasan diatas terlihat sangat jelas bahwa motivasi kerja yang diberikan oleh pimpinan pada UPT Pelabuhan Sungai Duku dapat meningkatkan kinerja pegawainya. Dengan pemberian motivasi yang berkatian dengan sikap terhadap pekerjaan. Serta pegawai yang berprestasi akan diberikan sebuah penghargaan atas hasil kerjanya.hal ini sesuai dengan teori yang di kemukakan oleh Hamza Buno (2014:59) menyatakan bahwa kinerja adalah fungsi-fungsi yang dituntut dari seseorang. Kinerja merupakan hasil inteksi atau berfungsinya unsur-usur motivasi, kemampuan, dan persepsi pada diri seseorang.

Komitmen Organisasional berpengaruh terhadap signifikan terhadap Kinerja Karyawan dengan nilai koefisien jalur 0.326 dan signifikasi t adalah 0.008. Komitmen Organisasional memediasi Motivasi Kerja terhadap Kinerja Karyawan. Berdasarkan hasil analisis jalur dapat disimpulkan bahwa variabel Motivasi Kerja melalui variabel antara Komitmen Organisasional memiliki pengaruh yang signifikan terhadap variabel terikat Kinerja Karyawan. Saran yang diberikan penulis kepada perusahaan adalah untuk semakin meningkatkan motivasi kerja karyawan dengan membangun rasa komitmen organisasional karyawan.

Pada kenyataanya, hasil penelitian ini memberikan gambaran bahwa komitmen organisasi pada UPT Pelabuhan Sungai Duku sudah baik, jika diperhatikan dari Affective Commitment, Continuence Commitment dan Normative Commitment. Hal ini sesuai dengan pendapay yang dikemukan oleh Wibowo (2014) yang menyatakan bahwa komitmen organisasi murapakan suatu tingkatan dimana individu mengidentivikasi dan terlibat dengan organisasinya dan atau tidak ingin meninggalkannya. Selanjutnya, komitmen organisasi juga memiliki pengaruh yang signifikan terhadap kinerja pegawai pada UPT Pelabuhan Sungai Duku Pekanbaru. Artinya semakin baik komitmen organisasi maka semakin baik kinerja pegawai dan sebaliknya, jika semakin menurun komitmen organisasi maka akan semakin menurun juga kinerja pegawai. Hasil penelitian ini sejalan dengan penelitian yang dilakukan oleh Hari Ginanjar (2021) yang menyimpulkan bahwa Komitmen organisasi berpengaruh signifikan terhadap kinerja karyawan.

Penelitian ini mendukung penelitian yang dilakukan oleh Yeh dan, Hong (2012) yang mengatakan bahwa yaitu Organizational Commitment will positively and significantly affect job performance. Hal ini menunjukkan bahwa karyawan bersedia untuk tinggal dan mengabdikan diri untuk mencapai tujuan pekerjaan karena mereka memiliki nilai yang sama dan tujuan dalam organisasi, Sebagai karyawan memiliki komitmen organisasi, produktifitas mereka akan meningkat dan begitu juga prestasi kerja. Sementara itu, supervisor harus memberikan penghargaan yang sesuai kepada bawahan ketika mereka mencapai tujuan pekerjaan. Pegawai dengan komitmen organisasi yang tinggi akan tetap berada dalam organisasi untuk menghindari biaya yang harus dikeluarkan bila mereka meninggalkan organisasi. Berdasarkan analisis kuesioner, 87\% responden merasakan terdapat keseimbangan antara gaji dan tanggung jawab yang dilakukan, mendapatkan kenaikan gaji berkala sesuai dengan kinerja yang telah 
dilakukan, dan responden merasa akan rugi secara moril dan materiil bila keluar dari UPT Pelabuhan Sungai Duku. Menurut McMurray, et al., (2004), komitmen organisasi dan kepercayaan pegawai yang tinggi terhadap organisasi secara signifikan merupakan salah satu determinan dalam pencapaian kinerja secara optimal. Berdasarkan analisis peneliti, pegawai mendapatkan insentif dari uang lembur dan tugas tambahan lainnya sehingga mengakibatkan dampak yang positif terhadap komitmen pegawai pada instansi tersebut.

\section{KESIMPULAN}

Berdasarkan hasil penelitian yang dilakukan, maka kesimpulan yang dapat dikemukakan dalam penelitian ini adalah sebagai berikut :

1. Hipotesis pertama menguji apakah motivasi berpengaruh signifikan terhadap komitmen organisasi pada UPT Pelabuhan Sungai Duku Pekanbaru. Hasil pengujian menunjukkan nilai nilai t-statistik variabel yaitu sebesar 4.391 dan p-values sebesar 0.000. Hasil pengujian membuktikan ada pengaruh yang signifikan, sehingga hipotesis pertama diterima. Hal tersebut membuktikan bahwa motivasi kerja terbukti memiliki pengaruh positif terhadap komitmen organisasi.

2. Hipotesis kedua menguji apakah motivasi berpengaruh signifikan terhadap kinerja pada UPT Pelabuhan Sungai Duku Pekanbaru. Hasil pengujian menunjukkan nilai tstatistik yaitu sebesar 4.414 dan p-values sebesar 0.000. Dari hasil ini dinyatakan pvalue lebih rendah dari alpha yaitu $0.000<0.05$. Hal ini membuktikan bahwa motivasi kerja berpengaruh signifikan terhadap kinerja pegawai pada UPT Pelabuhan Sungai Duku Pekanbaru.

3. Hipotesis ketiga menguji apakah komitmen organisasi berpengaruh signifikan terhadap kinerja karyawan pada UPT Pelabuhan Sungai Duku Pekanbaru. Hasil pengujian menunjukkan nilai t-statistik yaitu sebesar 2.832 dan p-values sebesar 0.005. Dari hasil ini dinyatakan p-value lebih rendah dari alpha yaitu $0.005<0.05$. Hal ini membuktikan bahwa komitmen organisasi berpengaruh signifikan terhadap kinerja pegawai pada UPT Pelabuhan Sungai Duku Pekanbaru. Dengan demikian hipotesis ke tiga di terima.

\section{DAFTAR PUSTAKA}

AA. Anwar Prabu Mangkunegara, 2013, Manajemen Sumber Daya Manusia Perusahaan, Penerbit Remaja Rosdakarya, Bandung

Adiftiya, Jajang. 2014. Pengaruh Komitmen Organisasi Terhadap Kinerja pada PT Bukit Makmur Utama Site Kideco Jaya Agung Batu Kajang Kabupaten Paser. Jurnal Administrasi dan Bisnis. Vol.2, No.13

Ahmadi. Edy Anas, Herwidyaningtyas, Fristina Bhakti, Fatimah. Siti. 2020. The Influence Of Organizational Culture, Work Motivation, And Job Satisfaction On Management Lecturer Performance (Empirical Study At Higher Education In The Residency Of Bojonegoro. Journal Of Industrial Engineering \& Management Research. Jilid 1. Terbitan 3 Halaman 76-83

Ahmadi. Edy Anas. 2020. Analisis Pengaruh Kualitas, Fitur, Dan Desain Produk Terhadap Keputusan Pembelian Honda Genuine Parts Di Jun's Motor Surabaya. Maker: Jurnal Manajemen. Jilid 6. Terbitan 2. Halaman. 148-156

Amanda, R. 2016. Pengaruh Pengawasan Terhadap Kinerja Karyawan Melalui Disiplin Kerja Sebagai Variabel Intervening di PT Astra International Tbk Waru pada Bagian Part \& Accesories (Depo) Regina Amanda. Jurnal Ilmu Manajemen, 4(4), $1-8$. 
Astuti, Diyah Riris. 2016. Manajemen Stres Kerja Pada Pegawai Di Mangrove Kaso Yogyakarta. Jurnal Manajemen Dakwah. Volume 1 hlm(16-56). Yogyakarta : Fakultas Dakwah dan Komunikasi UIN Sunan Kalijaga.

Bangun, Wilson. 2012. Manajemen Sumber Daya Manusia.Penerbit Erlangga, Jakarta Baldoni, John. 2015. Motivation, Secrets Of Greant Leaders. Mc Graw Hill, New York Brunetto, Y., and R. Farr-Wharton. 2013. The Impact of Government Policies and Practices on Australian SMEs. European Academy of Management Proceedings

Cardinal, 2010, Balancing and Rebalancing In the Creation and Revolution Of Organizational Control. Organization Science, Vol, 15, No. 4, Pp. 411-43

Colquitt, LePine, Wesson, 2011. Organizational Behavior Improving Performance and Commitment in The Workplace, International Edition, McGraw-Hill, New Yok.

Dinda Shara, Harum Febriani dan Suharnomo, 2018, Pengaruh Pengawasan, Motivasi Kerja, Dan Komunikasi Interpersonal Terhadap Kinerja Karyawan Dengan Komitmen Organisasi Sebagai Variabel Intervening (Studi pada PT. Pos Indonesia (Persero) Cabang Ungaran). Diponegoro Journal Of Management Volume 7, Nomor 1, Tahun 2018, Hal 1-12, ISSN (Online) : 2337-3792.

Edison, Emron. Yohny anwar,Imas Komariyah, 2016. Manajemen Sumber Daya Manusia. Penerbit Alfabeta, Bandung.

Edy, Sutrisno. 2012. Manajemen Sumber Daya Manusia. Penerbit Kencana, Jakarta

Erik Herlambang \& Fuadi, 2018, Pengaruhbudaya Organisasi dan Komunikasi Interpersonal Terhadap Kinerja Guru SMK Swasta Di Kota Serang Dengan Variabel Mediasi Komitmen Organisasi. Cendekia, Vol. 12, No. 1, April 2018, pISSN: 1978-2098; e-ISSN: 2407-8557

Fitria Agustina Sihombing, Merry Muspita Du, Ridwan Iskandar, 2016, Analisis Pengawasan dan Kompetensi terhadap Kepuasan Kerja Karyawan Melalui Kinerja pada PT. East West Seed Indonesia. Jurnal Ilmiah Inovasi · Vol 15, No 3

Gulick, Luther. 2011. Notes on the Theory of OrganizationClassics of Organization Theory, Brooks/Cole Publishing Company Pacific Grove, California

Hasibuan.Melayu. 2013. Manajemen Sumber Daya Manusia, Penerbit Bumi Aksara. Jakarta

Heller, Robert. 2013. Motivating People. London: Dorling Kindersley Book

Herzberg, Frederick. 2011. Herzbergees Motivation-Hygiene Theory and Job Satisfaction in The Malaysian Retail Sector: The Mediating Effect Of Love Money. Sunway University Malaysia: Teck Hang Tan and Amna Waheed

Hovland,C.I., Janis,I.L., dan Kelley. 2010. Communication and Persuation. New Haven : Yale University Press.

Ijewereme, O.B., Benson, K.S. 2013. Factors Influencing Performance Appraisal System in The Negarian Civil Service: A Comparative Study of Edo and Ondo States Civil Services of Nigeria. Journal of Public Policy and Administration Research, Vol. 3 No. 12, 130-139

Imron, Ali. 2012. Supervisi Pembelajaran Tingkat Satuan Pendidikan. Penebit Bumi Aksara, Jakarta

Irwan La Mane, dkk, 2020, Peran Disiplin Kerjadalam Memediasi Pengaruh Pengawasan Dan Motivasi Kerja Terhadap Kinerja Pegawai Lembaga Pembinaan Khusus Anak Kelas II Kendari, JUMBO (Jurnal Manajemen, Bisnis dan Organisasi), Vol. 4, No.1, April 2020, hal. 199-213e-ISSN 2502-4175

Koontz, Harold \& Cyril O’Donnel \& Heinz Weihrich. 2011. Manajemen. Jilid 2. Terjemahan: Gunawan Hutauruk. Penerbit Erlangga, Jakarta 
Kreitner, Robert dan Angelo Kinicki. 2014. Perilaku Organisasi. Edisi 9. Buku 1. Penebit Salemba Empat, Jakarta

Luthans, F. 2011. Organization Behavior (Eigth Edition). New York: The McGraw-Hall Co,INC

McShane, Steven L dan Von Glinow, Mary A. 2010. Organizational Behaviour Emerging Knowledge and Practice For The Real World 5 Edition. NewYork : McGraw-Hill.

Mondy, R.W dan Noe, R.M. 2015. Human Resource Management. Pearson Prentice Hall: New Jersey.

Nasri, 2019, Pengaruh Budaya Organisasi, Disiplin Kerja, Dan Komunikasi Interpersonal Terhadap Kinerja Pada Karyawan (Studi Pada PT Adidaya Bima Perkasa Yogyakarta). Jurnal Ekobis Dewantara Vol.2 No.2 Tahun 2019

Nurhawa, Badia Perizade, dan Agustina Hanafi, (2019), Pengawasan Dan Motivasi Terhadap Kinerja Dengan Komitmen Sebagai Variabel Intervening Pada RSUD Muaradua Oku Selatan, E-Jurnal Manajemen, Vol. 8, No. 12, 2019 : 7239-7259 ISSN : 2302-8912

Rio Andhika Putra dan Dori Mittra Candana, 2020, Pengaruh Motivasi Organisasi Dankomitmen Terhadap Kinerja Karyawandengan Organizational Citizenhip Behavior (OCB) Sebagai Variabel Interveningpada Karyawan Rumah Sakit Umum Daerah (RSUD) Dr. Muhammad Zein Painan. JEMSI : Jurnal Ekonomi Manajemen Sistem Informasi, Volume 2, Issue1, September, E-ISSN: 2686-5238, P-ISSN 2686-4916

Rivai Vitzal dan Ella Sagala, 2013, Manajemen Sumber Daya Manusia Untuk Perusahaan, Penerbit Rajawali Pers, Jakarta

R. Wayne and Faules, Don F, 2011. Komunikasi Organisasi, Penerbit Rosda Karya, Bandung

Schein, Edgar H., 2011, Organizational Culture and Leadership, Jossey Bass, San Francisco

Schermerhorn, J. R., Hunt, J. G., Osborn, R. N., dan Uhl-Bien, M, 2011. Organizational Behavior, 11th Edition. New Jersey: John Wiley \& Sons, Inc

Sedarmayanti. 2014. Sumber Daya Manusia dan Produktivitas Kerja. Penerbit Mandar Maju, Jakarta.

Sudarmanto, 2011. Kinerja dan Pengembangan Kompetensi SDM. Penerbit Pustaka Pelajar, Yogyakarta.

Terry, George R. 2011. Prinsip-prinsip Manajemen. Penerbit Bumi Aksara, Jakarta Wibowo. 2014. Perilaku Dalam Organisasi, Edisi 1-2 . Penerbit Rajawali Pers, Jakarta

Winda Kusuma Wardhani, dkk, 2015, Pengaruh Motivasi Kerja Karyawan Terhadap Komitmen Organisasional Dengan Kepuasan Kerja Sebagai Variabel Intervening, Jurnal Administrasi Bisnis (JAB), Vol. 2No. 1 Februari

Wijayanti, Irine Diana Sari. 2008, Manajemen, Editor: Ari Setiawan. Penerbit Mitra Cendikia, Yogyakarta 